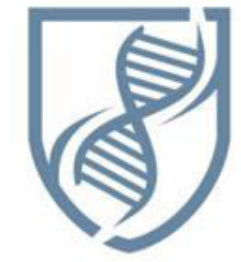

Journal of Bioscience and Applied Research

\section{JBAAR}

WWW.JBAAR.ORG

\title{
Therapeutic effectiveness of fenugreek seeds on pancreatic toxicity in young and adult male rats exposed to water nitrate pollution
}

\author{
Azza M. El-Wakf ; Ashraf Z. Mahamoud*; Hanaa A. Hassan, Abeer E. Abdrabouh. and \\ Marwa N. Habza \\ Zoology Department, Faculty of Science, Mansoura University, Egypt. \\ *Urology and Nephrology Center, Mansoura University, Egypt.
}

\begin{abstract}
Water nitrate pollution has been demonstrated to induce pancreatic toxicity, with increased risk of developing diabetes and exocrine pancreatic cancer. This study aimed to evaluate mechanisms that lead to pancreatic toxicity in nitrate exposed young and adult male rats, as well as the preventive effect of fenugreek seeds against these changes. Nitrate exposure of both ages showed almost identical changes, including significant reduction in serum insulin with elevation in blood glycosylated hemoglobin, serum glucose, acid phosphatase, $\alpha$-amylase and pancreatic tumor marker (carcinoembryonic antigen),indicating a tendency for developing diabetes, in association with pancreatic cancer which seemed of greatest value in the young group. An elevation in pancreas levels of nitric oxide, hydrogen peroxide and lipid peroxidation, with a reduction in the antioxidants; superoxide dismutase and catalase, as well as glutathione and its metabolizing enzymes; glucose -6- phosphate dehydrogenase and $\gamma$ - glutamyl transferase were also demonstrated. This goes with marked changes in insulin gene profile, as indicated by appearance of new band with a molecular weight $275 \mathrm{bp}$ and absence of three (1100, 825 and 750) bands as compared to the control of each age. Feeding fenugreek seeds powder to all nitrate exposed rats prevented changes in serum glucose, insulin, pancreatic tumor marker, oxidative stress biomarkers and insulin gene profile, indicating effectiveness of this plant to elicit cyto-protection against nitrate - induced pancreatic toxicity, probably through its antioxidant properties.
\end{abstract}

(Corresponding author e-mail: drazza_elwakf@yahoo.com)

Key words: Nitrate pollution; Pancreatic cancer; Antioxidants; Fenugreek; Insulin gene profile. 


\section{Introduction}

Nitrate contamination of drinking water is a major health problem for many people, particularly in the rural areas (Zhai Y et al., 2016). Although nitrate occurs naturally at low levels, human activities including uncontrolled use of nitrogenous fertilizers and improper disposal of animal manure or human waste can elevate levels of nitrate in sources of drinking water (Ward et al., 2005 and Stayner et al.,2017).At high levels, nitrates have been linked to a wide range of health hazards, including genotoxicity (BouazizKetata et al., 2015), renal insufficiency and liver damage ( Anwar and Mohamed, 2015). Experimentally, it was found that increased uptake of water contaminated with nitrate may cause; hypothyroidism, methemoglobinemia (El-Wakf et al.,2009a,b) and hypogonadism (El-Wakf et al., 2011).

An association between high nitrate levels and pancreatic toxicity was also reported. In particular, nitrate may cause chronic pancreatitis, coupled with diabetes which is more likely to occur in both young and adult population (Aschebrook- kilfoy et al., 2011; El-Wakf et al., 2015). Besides, increased nitrate exposure was suggested to increase risk of pancreatic cancer, which is mostly originated in the exocrine tissue and is classified as ductal adenocarcinoma (Debrin et al., 2008). Possible associations between onset of diabetes and pancreatic cancer have been postulated. Some studies evidenced that diabetes may be a causative factor for risk of pancreatic cancer (Ilic and Ilic, 2016). Others indicated that patients with diabetes have approximately twice the risk of developing pancreatic cancer compared with those without diabetes (Boursi et al., 2017). Although these findings are alarming, studies considering such association and the prevention strategies are limited or not available. Thus, a need has been felt for more investigations in this vital area.

Currently, numerous herbs are available as a safe and inexpensive approach for treatment and control of wide range of diseases. Fenugreek (Trigonella foenum graecum) is one of the oldest medicinal plants, dating back to ancient Egyptians where it was used in incense and to embalm mummies (Basch et al.,2003). Fenugreek seeds have also used as anti-inflammatory, antineoplastic (Shabbeer et al., 2009), antioxidant, hypoglycemic and hypocholesterolemic agent (Khole et al., 2014).Additionally, fenugreek seeds have shown to possess restorative and nutritive properties (Doshi et al.,2012) and to stimulate healing of different ulcers (Suja Pandian et al.,2002). Although fenugreek has been described widely for various medicinal properties, little is known about its use against toxic effects relevant to water pollution.

Regarding the above observations, the present study was designed to characterize whether increased exposure to nitrate polluted water is an etiologic factor for the association between diabetes and pancreatic cancer in both young and adult rats, with focusing on the underlying mechanisms. Also, to evaluate effectiveness of fenugreek seeds administration against these diseases.

The present work aimed to study whether nitrate polluted water had association between diabetes and pancreatic cancer in both young and adult rats. Also to focus on the underlying mechanisms and to evaluate the possible protective effect of fenugreek seeds administration against these diseases. 


\section{Materials and methods}

\subsection{Experimental animals}

This study was performed on healthy male Wistar rats of two ages; young ( 3 weeks old, $35 \pm 5$ gm) and adult (12 weeks old, $175 \pm 5$ gm) obtained from the Institute of Ophthalmic Disease Research, Cairo, Egypt. Rats were housed in ventilated cages in an automatically illuminated and thermally controlled room $\left(25 \pm 2{ }^{\circ} \mathrm{C}\right)$ with 12 -h light/dark cycle. Rats were fed a standard diet purchased from Meladco Feed Company (Aubor City, Cairo, Egypt) with free access to water. Experimental procedures were in accordance with the Ethical Principles adopted by Mansoura University for Care and Use of Laboratory Animals and the protocol prepared by the Institute of Laboratory Animal Resources, National Research Council "NRC" (NRC ,1995).

\subsection{Experimental diet}

Fenugreek (Trigonella foenum graecum) seeds were obtained from a store in Mansoura city. Fenugreek supplemented diet $(5 \% \mathrm{w} / \mathrm{w})$ was prepared according to El-Wakf et al.( 2015), where seeds were washed and dried, then crushed in an electric grinder. Fenugreek powder (50gm) was added to (950gm) standard diet together with some distilled water to form small pellets that left to dry in open air, then kept in clean plastic containers. The pellets were prepared once a week and preserved below $5{ }^{\circ} \mathrm{C}$ (Raju et al., 2001).

\subsection{Experimental design}

Experiments were started after one week of acclimation. Animals of each age were randomly di- vided into four groups (six animals each) as follows: Group I, normal control (NC) group; received normal diet with no additives. Group II (FG), animals were fed the experimental diet with fenugreek seeds' powder $(5 \% \mathrm{w} / \mathrm{w})$ as seen above. Group III (NT), animals were fed normal diet and allowed to uptake sodium nitrate $\left(\mathrm{NaNO}_{3}\right)$ dissolved in normal drinking water $(550 \mathrm{mg} / \mathrm{L})$ according to National Toxicology Program, (2001), where each rat approximately received 47.7 $\mathrm{mg} / \mathrm{kg} \mathrm{b.wt./day.} \mathrm{Group} \mathrm{IV} \mathrm{(NT+FG),} \mathrm{rats} \mathrm{were}$ received $\mathrm{NaNO}_{3}$ in water plus fenugreek supplemented diet in accordance with doses mentioned above. Animals were supplied with their respective treatments daily for period of four months.

\subsection{Blood and tissue sampling}

At the end of the study period, animals were fasted overnight then anesthetized using ether and sacrificed by cervical dislocation. From each of the studied rats, two blood samples were obtained; one on EDTA for glycosylated hemoglobin $(\mathrm{Hb}$ A1c)\% determination, while the second was left to coagulate, and centrifuged at $860 \mathrm{xg}$ for $15 \mathrm{~min}$ at $4^{\circ} \mathrm{C}$, then non hemolysed sera were collected and kept at $-80^{\circ} \mathrm{C}$ until hormonal and biochemical analysis. Pancreas was immediately removed and rinsed with ice-cold saline. Specimens of pancreas homogenate were taken, weighed and homogenized for biochemical analysis, while other specimens were removed and preserved at $-80^{\circ} \mathrm{C}$ for later molecular analysis. 


\subsection{Biochemical analysis}

In the tissue homogenates, reduced glutathione (GSH) was assessed according to the method achieved by Prins and Losse (1969), in which tungestate-sulfuric acid solution precipitated the protein content ,then after the reaction with 5, 5 dithiobis-2nitrobenzoic acid (DTNB) yellow color is formed. The absorbance was determined within $30-60 \mathrm{sec}$ at $412 \mathrm{~nm}$ against the blank. Superoxide dismutase (SOD) activity was assayed as described by Nishikimi et al. (1972). The assay relies on the ability of the enzyme to inhibit phenazine methosulphate mediated reaction of nitroblue tetrazolium dye and the increase in absorbance after 5 min was measured at $560 \mathrm{~nm}$. Catalase (CAT) activity was determined according to the method of Bock et al. (1980), based on the ability of CAT to decompose $\mathrm{H}_{2} \mathrm{O}_{2}$. The decomposition of $\mathrm{H}_{2} \mathrm{O}_{2}$ can be followed directly by the decrease in absorbance at $240 \mathrm{~nm}$. The difference in absorbance per unit time is a measure of CAT activity. The level of malondialdehyde (MDA), the end product of lipid peroxidation (LPO) was determined as thiobarbituric acid reactive substance (TBARS) according to the modified method of Ohkawa et al. (1979). Serum carcinoembryonic antigen (CEA) was estimated according to the electrochemiluminescence immunoassay "ECLIA" intended for use on Roche Elecsys1010 immunoassay analyzer (Guder et al., 1996). Serum insulin was estimated using INSEASIA kit according to the immune-enzymatic assay (Temple et al., 1992), while HbA1c \% was determined using Teco diagnostics kit obtained from United States (Gonen and Rubenstein,1978).

\section{Other biochemical parameters}

Biochemical parameters encompassing, glucose, acid phosphatase (ACP), glucose -6- phosphate dehydrogenase (G-6-PD), $\gamma$-glutamyl transferase $(\gamma$ GT), $\alpha$ - amylase, nitric oxide (NO) and hydrogen peroxide $\left(\mathrm{H}_{2} \mathrm{O}_{2}\right)$ were assessed using kits supplied by Bio Diagnostic Company for diagnostic reagents (Dokki,Giza, Egypt).

\subsection{Molecular analysis \\ DNA extraction}

For DNA extraction, pancreatic specimens were homogenized in $5 \mathrm{ml}$ sterile distilled water .The homogenate $(350 \mu \mathrm{l})$ was mixed with $0.6 \mathrm{ml}$ of digestion buffer and $0.1 \mathrm{ml}$ proteinase $\mathrm{K}(50 \mathrm{mg} / \mathrm{ml})$, vortexed and incubated overnight in water bath at $55{ }^{\circ} \mathrm{C}$ till clearing. Samples were mixed with equal volumes of phenol-chloroform isoamyl alchol, centrifuged at $18626 \mathrm{xg}$ for $3 \mathrm{~min}$ and the supernatant was transferred to a new eppendorf tube. To get rid of RNA, $0.003 \mathrm{ml}$ RNase solution was added, mixed thoroughly and incubated in a water bath at $37^{\circ} \mathrm{C}$ for 30 min. DNA was precipitated by adding sodium chloride solution (1M ) and iso-propanol. Mixture was inverted several times till fine fibers of DNA appeared, then centrifuged at $18626 \mathrm{xg}$ for $3 \mathrm{~min}$ and the supernatant was removed. For washing, $1 \mathrm{ml}$ of $70 \%$ ethyl alcohol was added and centrifuged for 3 min at $18626 \mathrm{xg}$. DNA was collected, dried and reconstituted in a suitable volume of sterile deionozed water and stored at $4{ }^{\circ} \mathrm{C}$ until use (Ausubel et al.,1999). 


\section{Polymerase chain reaction $(\mathrm{PCR})$}

Equal volumes $(1 \mu \mathrm{l})$ of genomic DNA and each of insulin gene primers fforward (ACCACCA G CCCTAA- GTGATCCGCTA) and \{reverse (AAGGTTTTATTCATTGCAGAGGGGT) $\}$ were mixed with one PCR bead. Mixture was completed to $20 \mu$ with sterile deionized water, inverted many times and collected again by spin at maximum speed, followed by centrifugation for $5 \mathrm{sec}$ at $18626 \mathrm{xg}$.

For insulin gene amplification, PCR mixture was transferred to thermal cycler programmed for 40 cycles as follows:

$1 \mathrm{~min}$ at $94{ }^{\circ} \mathrm{C}$ for DNA denaturing, $1 \mathrm{~min}$ at 57 ${ }^{\circ} \mathrm{C}$ for annealing and $2 \mathrm{~min}$ at $72{ }^{\circ} \mathrm{C}$ for new DNA extension, followed by final DNA extension at $72{ }^{\circ} \mathrm{C}$ for $7 \mathrm{~min}$. PCR product and 75-20000 bp DNA ladder (Gene Ruler ${ }^{\text {TM }}$ ) were mixed with bromophenol blue loading dye (6x) then analyzed by electrophoresis on $1 \%$ agarose gel mixed with ethidium bromide and the amplified DNA bands were visualized under UV light (Sambrook $e t$ al.,1998).

\section{Statistical analysis}

Data analysis was done using SPSS statistical package software (version 17) for multiple variable comparisons by one way analysis of variance (Oneway ANOVA) followed by post hoc least significant differnce (LSD) test. Data obtained from each group were expressed as means \pm SE. The level of significance was set as $p \leq 0.05$ (Snedecor and Cochran,1980).

\section{Results}

\subsection{Serum biochemical parameters}

Feeding fenugreek supplemented diet to normal animals of both ages showed significantly reduced serum carcinoembryonic antigen (CEA), $\alpha$-amylase and acid phosphatase (ACP) activities only in the young group, while serum glucose, insulin and $\mathrm{Hb}$ A1c\% showed non-significant changes compared to normal control (NC) animals. However, consumption of drinking water contaminated by $\mathrm{NaNO} 3$ $(550 \mathrm{mg} / \mathrm{L})$ exhibited significant elevation in serum glucose, $\mathrm{Hb} \mathrm{A} 1 \mathrm{c} \%, \mathrm{ACP}$ and CEA, while a significant reduction in insulin level was recorded in the two studied age groups, particularly, the young compared to their control groups. The above alterations tended to be restored near to normal values on feeding fenugreek diet with nitrate contaminated water uptake in both ages relative to their nitrate exposed groups (Table 1). 


\subsection{Pancreas biochemical parameters}

Obtained results revealed significantly elevated pancreatic (SOD, CAT, $\gamma$-GT and GSH) and significantly reduced LPO, NO and $\mathrm{H}_{2} \mathrm{O}_{2}$, with non significantly changed G-6-PD activity in fenugreek fed normal rats of both ages compared to corresponding control groups. On contrast, pancreatic (SOD, CAT, GSH, G-6-PD and $\gamma$-GT) were significantly reduced, but LPO, $\mathrm{NO}$ and $\mathrm{H}_{2} \mathrm{O}_{2}$ were significantly increased in all nitrate exposed animals, especially in the young ones compared to the control animals. It should also be noted that fenugreek administration with nitrate was found to alleviate such nitrate-induced biochemical changes on comparing to nitrate exposed groups (Table 2).

3.3.Insulin gene changes

A s illustrated in Figure 1 and 2, the extracted pancreatic DNA gave positive PCR reaction when amplified by insulin gene primers. Generally, the two age groups were identical to each other regard- ing the PCR profiles; where the control of each age group (lane 1) produced four main bands with molecular weights 1100, 825, 750 and 600 bp. Similarly, fenugreek groups of both young and adult animals (lanes 2,3) produced the same profile and bands like the control. In nitrate group, the first sample of each age (lanes 4) produced the same four main bands 1100, 825, 750 and 600 bp like the control; beside a new band with a molecular weight 275 bp was appeared. While the second sample (lane 5) was highly different from the control, in which three bands $(1100,825$ and 750) of the four main bands were completely disappeared. Thus, nitrate exposure can be considered mutagenic for insulin gene in both young and adult animals. On contrast, PCR product of nitrate + fenugreek group of both ages (lanes 6,7) showed a pattern near to the control groups in having the same four main bands 1100, 825, 750 and $600 \mathrm{bp}$, indicating the ability of fenugreek to protect against nitrateinduced insulin gene mutation 
Table 1 : Serum tested parameters of all studied experimental groups

\begin{tabular}{|c|c|c|c|c|c|c|c|c|}
\hline \multirow{3}{*}{$\begin{array}{c}\text { Tested } \\
\text { Parameters }\end{array}$} & \multicolumn{8}{|c|}{ Animal groups } \\
\hline & \multicolumn{4}{|c|}{ Young groups } & \multicolumn{4}{|c|}{ Adult groups } \\
\hline & NC & FG & NT & $\mathbf{N T}+\mathrm{FG}$ & NC & FG & NT & NT+FG \\
\hline $\begin{array}{l}\text { Glucose } \\
\text { (mg/dl) }\end{array}$ & $107.29 \pm 0.38$ & $\begin{array}{l}97.28 \mathrm{a} \pm 0.36 \\
\quad(-9.33)\end{array}$ & $\begin{array}{c}179.68^{\mathrm{a}} \pm 1.85 \\
(+67.47)\end{array}$ & $\begin{array}{c}116.76^{a c} \pm 0.51 \\
(+8.83)\end{array}$ & $105.40 \pm 1.25$ & $\begin{array}{c}100.13^{b} \pm 0.59 \\
(-5.00)\end{array}$ & $\begin{array}{c}161.81^{b} \pm 2.15 \\
(+53.52)\end{array}$ & $\begin{array}{c}114.71^{\mathrm{bd}} \pm 1.74 \\
(+8.83)\end{array}$ \\
\hline Hb A1c\% & $3.07 \pm 0.15$ & $\begin{array}{c}3.05 \pm 0.08 \\
(-0.65)\end{array}$ & $\begin{array}{c}4.62^{\mathrm{a}} \pm 0.18 \\
(+50.49)\end{array}$ & $\begin{array}{c}3.27^{c} \pm 0.03 \\
(+6.51)\end{array}$ & $3.32 \pm 0.09$ & $\begin{array}{c}3.30 \pm 0.13 \\
(-0.60)\end{array}$ & $\begin{array}{c}4.27^{b} \pm 0.13 \\
(+28.61)\end{array}$ & $\begin{array}{c}3.38^{\mathrm{d}} \pm 0.06 \\
(+1.81)\end{array}$ \\
\hline $\begin{array}{l}\text { Insulin } \\
(\mu \mathrm{IU} / \mathrm{ml})\end{array}$ & $1.38 \pm 0.06$ & $\begin{array}{c}1.40 \pm 0.01 \\
(+1.45)\end{array}$ & $\begin{array}{c}1.16^{\mathrm{a}} \pm 0.01 \\
(-15.94)\end{array}$ & $\begin{array}{c}1.30^{\mathrm{ac}} \pm 0.01 \\
(-5.80)\end{array}$ & $1.34 \pm 0.01$ & $\begin{array}{c}1.35 \pm 0.01 \\
(+0.75)\end{array}$ & $\begin{array}{c}1.15^{\mathrm{b}} \pm 0.003 \\
(-14.18)\end{array}$ & $\begin{array}{c}1.28^{\mathrm{bd}} \pm 0.01 \\
\quad(-4.48)\end{array}$ \\
\hline $\begin{array}{l}\text { ACP } \\
(\mathbf{U} / \mathbf{L})\end{array}$ & $32.89 \pm 0.93$ & $\begin{array}{c}27.91^{\mathrm{a}} \pm 0.49 \\
(-15.14)\end{array}$ & $\begin{array}{c}61.82^{a} \pm 1.41 \\
(+87.96)\end{array}$ & $\begin{array}{c}40.16^{\mathrm{ac}} \pm 0.35 \\
(+22.10)\end{array}$ & $36.17 \pm 0.57$ & $\begin{array}{c}32.46^{b} \pm 0.28 \\
(-10.26)\end{array}$ & $\begin{array}{c}56.04^{b} \pm 0.57 \\
(+54.94)\end{array}$ & $\begin{array}{c}38.48^{\text {bd }} \pm 0.56 \\
(+6.39)\end{array}$ \\
\hline $\begin{array}{c}\alpha \text {-amylase } \\
(\mathrm{U} / \mathrm{L})\end{array}$ & $7.10 \pm 0.29$ & $\begin{array}{c}6.82 \pm 0.28 \\
-3.94\end{array}$ & $\begin{array}{c}10.49^{\mathrm{a}} \pm 0.25 \\
+47.75\end{array}$ & $\begin{array}{c}7.41^{c} \pm 0.04 \\
+4.37\end{array}$ & $8.55 \pm 0.04$ & $\begin{array}{c}8.49 \pm 0.02 \\
-0.70\end{array}$ & $\begin{array}{c}9.32^{b} \pm 0.08 \\
+9.01\end{array}$ & $\begin{array}{c}8.85 \pm 0.03 \\
\quad+3.51\end{array}$ \\
\hline $\begin{array}{l}\text { CEA } \\
\text { (ng/dl) }\end{array}$ & $28.50 \pm 0.07$ & $\begin{array}{c}27.79^{\mathrm{a}} \pm 0.08 \\
\quad(-2.49)\end{array}$ & $\begin{array}{c}29.55^{\mathrm{a}} \pm 0.04 \\
(+3.68)\end{array}$ & $\begin{array}{c}28.87^{\mathrm{ac}} \pm 0.03 \\
(+1.30)\end{array}$ & $28.60 \pm 0.14$ & $\begin{array}{c}28.35 \pm 0.09 \\
(-0.87)\end{array}$ & $\begin{array}{l}29.33^{\mathrm{b}} \pm 0.11 \\
\quad(+2.55)\end{array}$ & $\begin{array}{l}28.65^{\mathrm{d}} \pm .17 \\
\quad(+0.17)\end{array}$ \\
\hline
\end{tabular}

- Values are means \pm SE of 6 animals for each group. The values in parentheses are percentage of change from control.

- Values bearing superscript are significantly different by ANOVA test at $p \leq 0.05$.

NC: normal Control, FG: Fenugreek, NT: Nitrate, NT+FG: nitrate +fenugreek.

a: significant as compared to young control group ,b: significant as compared to adult control group.

c: significant as compared to young nitrate group ,d: significant as compared to adult nitrate group. 
Table 2. Pancreas tested parameters of all studied experimental groups

\begin{tabular}{|c|c|c|c|c|c|c|c|c|}
\hline \multirow{3}{*}{$\begin{array}{c}\text { Tested } \\
\text { parameters }\end{array}$} & \multicolumn{8}{|c|}{ Animal groups } \\
\hline & \multicolumn{4}{|c|}{ Young group } & \multicolumn{4}{|c|}{ Adult group } \\
\hline & $\mathrm{NC}$ & FG & NT & $\mathbf{N T}+\mathbf{F G}$ & $\mathrm{NC}$ & FG & NT & $\mathbf{N T}+\mathbf{F G}$ \\
\hline $\begin{array}{c}\text { SOD } \\
\text { (U/g wet tissue) }\end{array}$ & $\begin{array}{c}131.33 \pm 1 \\
34\end{array}$ & $\begin{array}{l}145.44^{\mathrm{a}} \pm 1.15 \\
\quad(+10.74)\end{array}$ & $\begin{array}{c}91.32^{\mathrm{a}} \pm 2.4 \\
7 \\
(-30.47)\end{array}$ & $\begin{array}{c}124.79^{\mathrm{ac}} \pm 0.59 \\
(-4.98)\end{array}$ & $\mid \begin{array}{c}138.93 \pm 1.9 \\
2\end{array}$ & $\begin{array}{c}145.61^{b} \pm 0.99 \\
(+4.81)\end{array}$ & $\begin{array}{c}99.52^{\mathrm{b}} \pm 2.25 \\
(-28.37)\end{array}$ & $\begin{array}{c}133.72^{\mathrm{bd}} \pm 0.89 \\
(-3.75)\end{array}$ \\
\hline $\begin{array}{c}\text { CAT } \\
\text { ( } \mu \mathrm{mol} / \mathrm{sec} / \mathrm{g} \text { wet } \\
\text { tissue })\end{array}$ & $2.51 \pm 0.04$ & $\begin{array}{c}3.19^{a} \pm 0.15 \\
(+27.09)\end{array}$ & $\begin{array}{c}0.47^{\mathrm{a}} \pm 0.01 \\
(-81.27)\end{array}$ & $\begin{array}{c}2.48^{c} \pm 0.06 \\
(-1.19)\end{array}$ & $2.80 \pm 0.20$ & $\begin{array}{c}3.54^{b} \pm 0.37 \\
(+26.43)\end{array}$ & $\begin{array}{c}0.69^{b} \pm 0.02 \\
(-75.36)\end{array}$ & $\begin{array}{c}2.76^{\mathrm{d}} \pm 0.05 \\
(-1.61)\end{array}$ \\
\hline $\begin{array}{c}\gamma \text {-GT } \\
\text { (U/g wet tissue) }\end{array}$ & $\begin{array}{c}22.09 \pm 0.3 \\
4\end{array}$ & $\begin{array}{c}42.17^{\mathrm{a}} \pm 0.7 \\
5 \\
(+90.90)\end{array}$ & $\begin{array}{c}10.75^{\mathrm{a}} \pm 0.3 \\
5 \\
(-51.34)\end{array}$ & $\begin{array}{c}9.54^{\mathrm{ac}} \pm 0.02 \\
(-11.54)\end{array}$ & $\begin{array}{c}40.82 \pm 0.7 \\
3\end{array}$ & $\begin{array}{c}53.63 \\
(+31.38)\end{array}$ & $\begin{array}{c}30.80^{b} \pm 1.1 \\
1 \\
(-24.55)\end{array}$ & $\begin{array}{c}40.28^{d} \pm 0.50 \\
(-1.32)\end{array}$ \\
\hline $\begin{array}{c}\text { G-6-P-D } \\
\text { (mU/g wet } \\
\text { tissue) }\end{array}$ & $\begin{array}{c}40.26 \pm 0.4 \\
0\end{array}$ & $\begin{array}{c}41.04 \pm 0.82 \\
\quad(+1.94)\end{array}$ & $\begin{array}{c}25.07^{a} \pm 0.4 \\
5 \\
(-37.73)\end{array}$ & $\begin{array}{c}35.80^{\mathrm{ac}} \pm 0.24 \\
(-11.08)\end{array}$ & $\begin{array}{l}38.08 \pm 0.0 \\
6\end{array}$ & $\begin{array}{c}38.65 \pm 0.26 \\
(+1.50)\end{array}$ & $\begin{array}{c}24.36^{b} \pm 0.7 \\
1 \\
(-36.03)\end{array}$ & $\begin{array}{c}34.20^{\mathrm{bd}} \pm 0.7 \\
2 \\
(-10.19)\end{array}$ \\
\hline $\begin{array}{c}\text { GSH } \\
\text { (mg/100g wet } \\
\text { tissue) }\end{array}$ & $\begin{array}{c}22.50 \pm 0.3 \\
4\end{array}$ & $\begin{array}{c}24.85^{\mathrm{a}} \pm 0.9 \\
0 \\
(+10.44)\end{array}$ & $\begin{array}{c}15.80^{\mathrm{a}} \pm 0.54 \\
(-29.78)\end{array}$ & $\begin{array}{c}20.40^{\mathrm{ac}} \pm 0.40 \\
(-9.33)\end{array}$ & $34.00 \pm 0.73$ & $\begin{array}{c}36.92^{\mathrm{b}} \pm 0.58 \\
(+8.59)\end{array}$ & $\begin{array}{c}27.29^{b} \pm 0.44 \\
(-19.74)\end{array}$ & $\begin{array}{c}32.92^{d} \pm 0.45 \\
(-3.18)\end{array}$ \\
\hline $\begin{array}{c}\text { LPO } \\
\text { (nmol/g wet } \\
\text { tissue) }\end{array}$ & $\begin{array}{l}302.85 \pm 0 . \\
91\end{array}$ & $\begin{array}{c}296.68^{\mathrm{a}} \pm 1.73 \\
(-2.04)\end{array}$ & $\begin{array}{c}400.21^{\mathrm{a}} \pm 2.19 \\
\quad(+32.15)\end{array}$ & $\begin{array}{c}312.36^{\mathrm{ac}} \pm 0.97 \\
(+3.14)\end{array}$ & $473.56 \pm 0.70$ & $\begin{array}{c}465.56^{b} \pm 1.11 \\
\quad(-1.69)\end{array}$ & $\begin{array}{c}595.57^{\mathrm{b}} \pm 1.12 \\
(+25.76)\end{array}$ & $\begin{array}{c}514.44^{\text {bd }} \pm 0.53 \\
(+8.63)\end{array}$ \\
\hline $\begin{array}{c}\text { NO } \\
(\mu \mathrm{mol} / \mathrm{g} \text { wet } \\
\text { tissue })\end{array}$ & $\begin{array}{c}11.96 \pm 0.1 \\
9\end{array}$ & $\begin{array}{c}10.28^{a} \pm 0.0 \\
9 \\
(-14.05)\end{array}$ & $\begin{array}{c}14.76^{\mathrm{a}} \pm 0.3 \\
1 \\
(+23.41)\end{array}$ & $\begin{array}{c}12.32^{c} \pm 0.39 \\
(+3.01)\end{array}$ & $\begin{array}{c}11.87 \pm 0.0 \\
4\end{array}$ & $\begin{array}{c}10.33^{b} \pm 0.1 \\
0 \\
(-12.97)\end{array}$ & $\begin{array}{c}14.30^{b} \pm 0.2 \\
5 \\
(+20.47)\end{array}$ & $\begin{array}{l}12.19^{d} \pm 0.11 \\
(+2.70)\end{array}$ \\
\hline $\begin{array}{c}\mathrm{H}_{2} \mathrm{O}_{2} \\
\text { (mM/g wet } \\
\text { tissue) }\end{array}$ & $1.27 \pm 0.03$ & $\begin{array}{c}0.91^{\mathrm{a}} \pm 0.01 \\
(-28.35)\end{array}$ & $\begin{array}{c}3.79^{\mathrm{a}} \pm 0.07 \\
(+198.43)\end{array}$ & $\begin{array}{c}1.49^{\mathrm{ac}} \pm 0.01 \\
(+17.32)\end{array}$ & $1.07 \pm 0.04$ & $\begin{array}{c}0.88^{\mathrm{b}} \pm 0.02 \\
(-17.76)\end{array}$ & $\begin{array}{l}2.15^{b} \pm 0.04 \\
(+100.93)\end{array}$ & $\begin{array}{l}1.24^{b d} \pm 0.07 \\
(+15.89)\end{array}$ \\
\hline
\end{tabular}

- Values are means \pm SE of 6 animals for each group. The values in parentheses are percentage of change from control.

- Values bearing superscript are significantly different by ANOVA test at $p \leq 0.05$.

NC: normal Control, FG: Fenugreek, NT: Nitrate, NT+FG: nitrate +fenugreek.

a: significant as compared to young control group ,b: significant as compared to adult control group.

c: significant as compared to young nitrate group ,d: significant as compared to adult nitrate group. 


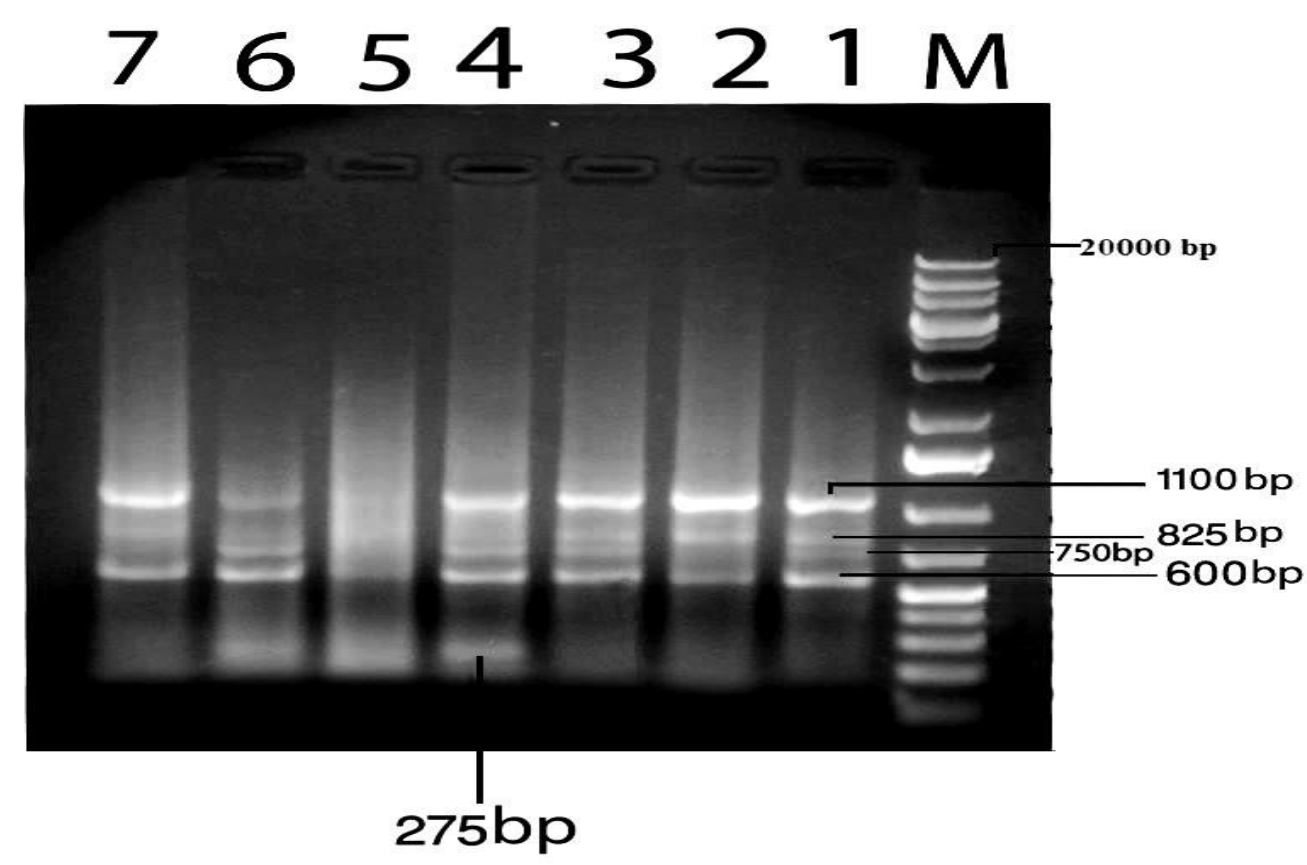

Figure 1 : Agarose gel electrophoresis of PCR product from pancreatic tissue in different young groups. Lane 1 is control (NC), lanes 2,3 is fenugreek (FG), lanes 4, 5 are nitrate (NT) and lanes 6, 7 are nitrate with fenugreek (NT+FG) respectively. Lane $M$ is 1kb ladder "75- 20000 bp" DNA marker.

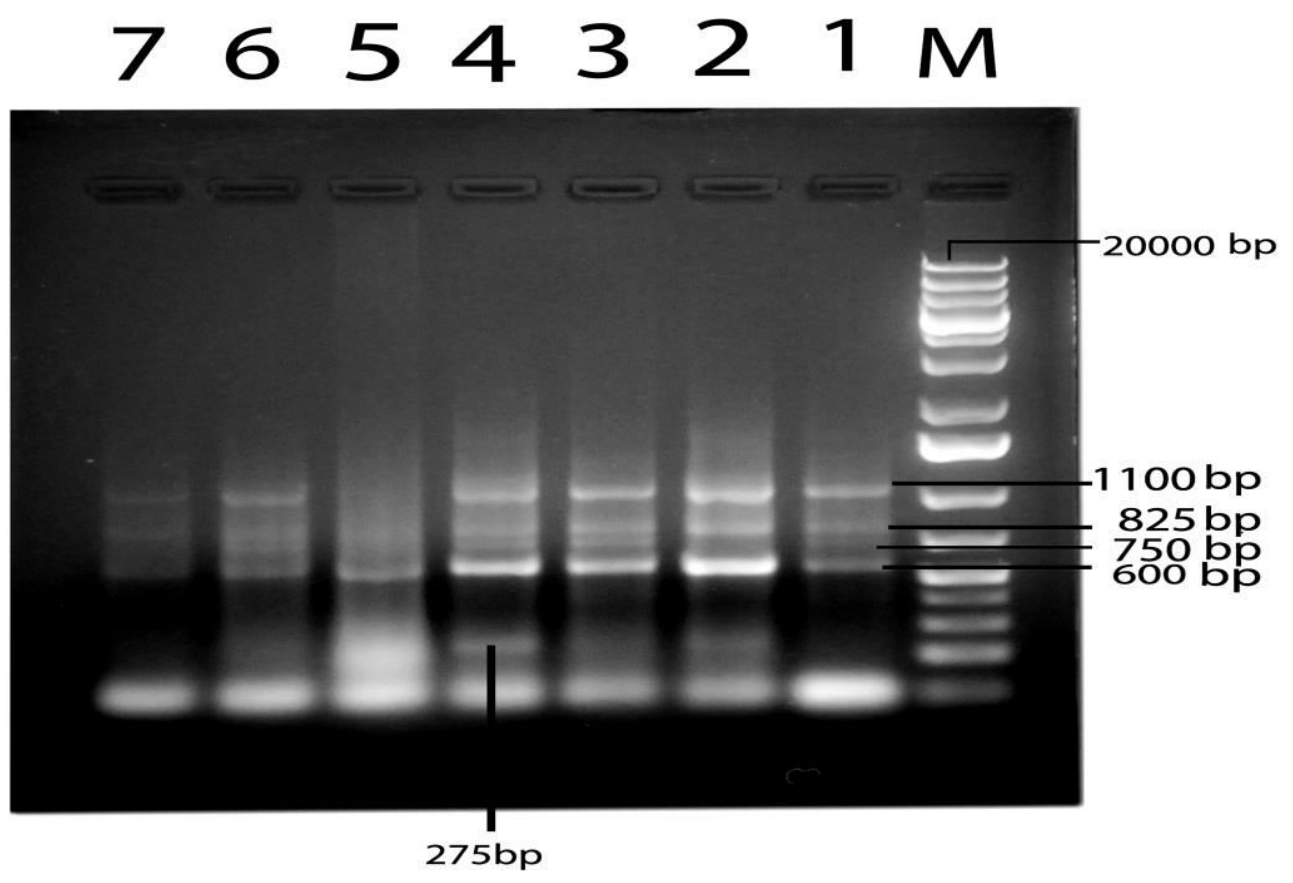

Figure 2: Agarose gel electrophoresis of PCR product from pancreatic tissue in different adult groups. Lane 1 is control (NC), lanes 2,3 are fenugreek (FG), lanes 4, 5 are nitrate (NT) and lanes 6, 7 are nitrate with fenugreek (NT+FG) respectively. Lane $M$ is 1kb ladder "75- 20000 bp" DNA marker. 


\section{Discussion}

Various studies have addressed a relation between incidence of diabetes and nitrate exposure (Marienfeld et al., 2007; Benson et al.,2010; ElWakf et al., 2015). Others extended to describe nitrate as a causative or inductive factor for pancreatic cancer that predominantly arises in the exocrine portion (Debrin et al., 2008). Thus, suggesting nitrate as an environmental toxicant for both exocrine and endocrine pancreas. Subsequently, a correlation between diabetes and pancreatic cancer has been suggested by several researchers (Pannala et al., 2009; Zavoral et al., 2011).

Observations from clinical studies indicated that diabetic patients have a risk of evolving pancreatic cancer approximately twice the nondiabetic ones (Huxley et al., 2005). Also, there is evidence that the majority of diabetics associated with pancreatic cancer is diagnosed either concomitantly with the cancer or before cancer was developed (Pannala et al., 2009).Therefore, it appears appropriate to suggest that recentlydeveloped pancreatic cancer may be a consequence of diabetes and that events associated with diabetes are involved in promoting the development of pancreatic cancer .

In the current study, nitrate exposed rats exhibited marked diabetic state, characterized by elevation in glucose concentration and $\mathrm{Hb} \mathrm{A} 1 \mathrm{c} \%$, accompanied with reduction in insulin level. The study also revealed higher tendency for pancreatic cancer, through elevated serum level of carci- noembryonic antigen (CEA) that often accompany conditions of pancreatic tumor (Yegneswaran and Pitchumoni, 2010). This goes concomitantly with shift towards elevation in serum $\alpha$-amylase activity. Although $\alpha$-amylase is mostly used to detect pancreatitis; increased pancreatic output of amylase with elevation of its serum level is indicative to exocrine pancreatic cancer in some studies (Rückert et al., 2010). For all, the present study tends to suggest that high nitrate intake from drinking water is potentially toxic for both endocrine and exocrine pancreas, with a link between diabetes and pancreatic cancer may exist in the two tested age groups, in particular the young one. A result that may be explained by the fact that young individuals usually have low gastric acidity, where nitrate favors conversion to other toxic nitrogen compounds that increased susceptibility at the young age (Gupta et al., 2008; ElWakf et al., 2009a,b). As support, it was reported that gastric acidity of the young children is not as strong as adults that favors the growth of nitrate-reducing bacteria, leading to conversion of nitrates into high levels of the potentially toxic nitrites $\left(\mathrm{NO}_{2}\right)($ Kusaka et al.,2016).

Previously, it was indicated that nitrate toxicity relies mainly on its ability to generate oxygen free radicals and to induce oxidative stress (El-Wakf et al., 2011).Therefore, it appears appropriate to suggest oxidative stress as a general pathophysiological pathway by which nitrate exposure can lead to diabetes in association with 
pancreatic cancer. Related to this, it was evidenced that diabetes and pancreatic cancer may share a number of underlying mechanisms; however oxidative stress may play a key role (Malati 2007; Abdal Dayem et al., 2010).

Findings from the present study demonstrated increased pancreatic $\mathrm{H}_{2} \mathrm{O}_{2}$ and NO following nitrate exposure which in turn may elicit oxidative stress as contributing factor in developing diabetes. In support, it was reported that nitrate can cause oxidative damage to pancreas through elevation of $\mathrm{H}_{2} \mathrm{O}_{2}$ and $\mathrm{NO}$ (Brindicci et al.,2010). Moreover, it was explained that the major target of nitrate damaging species $\left(\mathrm{H}_{2} \mathrm{O}_{2}\right.$ and $\left.\mathrm{NO}\right)$ is pancreatic $\beta$-cells, which are particularly prone to attack because $\beta$-cells are unique in containing low levels of free radicals- scavenging enzymes (Wierusz-Wysocka et al.,1997). A relation between in vivo NO and onset of diabetes has been consequently evidenced. This effect is probably linked to interaction of $\mathrm{NO}$ with superoxide anion $\left(\mathrm{O}^{-}\right)$to form peroxynitrite $\left(\mathrm{ONOO}^{-}\right)$which is tissue destructive (Brindicci et al., 2010). Peroxynitrite may also considered mutagenic because it can cause deamination of DNA and inactivation of DNA repair enzymes (Hou et al.,2007). Besides, peroxynitrite can oxidize DNA and may potentially cause single-strand DNA breaks through attack on the sugar-phosphate backbone (Xu et al.,2002). Considering this, it can suggest that increased $\mathrm{H}_{2} \mathrm{O}_{2}$ and $\mathrm{NO}$ in response to nitrate exposure may enhance pancreatic DNA damage, causing insulin gene mutations, as seen in the current study. An effect which may directly aid in developing diabetes.
In parallel, a number of studies have suggested increased free radicals and oxidative stress to play a key role in initiation and progression of organs carcinogenesis, including pancreatic cancer (Crohns et al., 2013). In particular, oxidative stress has been reported to affect cellular membrane integrity which in turn may affect structure and function of cellular organelles, as lysosomes. Increased activity of lysosomal enzymes, as acid phosphatase was linked with certain types of cancer in human (Goto et al., 2001; Malati 2007). Accordingly, the presently increased activity of acid phosphatase in serum of nitrate exposed rats may be considered as marker of oxidative stress contributing to development of pancreatic cancer.

Increased oxidative stress refers to an imbalance between intracellular production of reactive oxygen species (ROS) and the cellular defense mechanisms. Oxidative stress is known to be associated with increased lipid peroxidation and reduced antioxidant activity. Lipid peroxidation arises due to conversion of cellular polyunsaturated fatty acids to toxic products known as lipid peroxides, including malondialdhyde (MDA). Owing to MDA cytotoxicity and inhibitory action on cellular protective enzymes, it is suggested to act as a tumor promoter (Manimaran and Rajneesh, 2009). Accumulation of MDA is emphasized to increase during carcinogenesis with accompanying depletion of SOD and CAT activities and GSH content (Amin et al.,2012). SOD is considered the first line of defense against deleterious effects of oxygen free radicals in the cells by catalyzing dismutation of superoxide radicals $\left(\mathrm{O}^{-}\right)$to $\mathrm{H}_{2} \mathrm{O}_{2}$ and molecular oxygen. CAT is responsible for detoxification of 
$\mathrm{H}_{2} \mathrm{O}_{2}$ which is an effective inhibitor of SOD (De duve and Baudhhuin 1996); thus the reduction in the activity of CAT may reflect inability of tissues to eliminate $\mathrm{H}_{2} \mathrm{O}_{2}$. CAT protects SOD against inactivation by $\mathrm{H}_{2} \mathrm{O}_{2}$, while SOD protects $\mathrm{CAT}$ against inhibition by $\mathrm{O}^{-}$. Thus, the balance of this enzyme system may be essential to get rid of ROS generated in the tissues. In this concern, GSH represents an important defense mechanism in protecting cells against ROS. Decreased GSH content may be occurred by reduced activity of the enzymes, G-6-PD and $\gamma$-GT being required for maintaining cellular GSH level (El-Wakf 1996; Ansari and Mahmood, 2015) .This effect when taken with reduced activities of both SOD and CAT may indicate enhanced oxidative stress leading to increased risk of pancreatic cancer, as seen in the current study.

Dietary habits and nutrition are known to play important role in alleviating oxidative stress being related to development of several health problems (Prabhu and Krishnamoorthy 2010). Fenugreek is a herb whose seeds and leaves are used not only as food but also as ingredients in the traditional medicine. Recently, fenugreek seeds have been demonstrated to posses a number of phytochemicals being accepted as natural antioxidants. These include vitamins, flavonoids, terpenoids, carotenoids, coumarins, curcumins, lignin and saponin (Zheng and Wang 2001). As support, it was demonstrated that fenugreek seeds prevented in vitro oxidative hemolysis and lipid peroxidation induced by $\mathrm{H}_{2} \mathrm{O}_{2}$ in human erythrocytes (Kaviarasan et al., 2004; Al-Amri and Alrasheedi,2016). Moreover, dietary supplementation with fenugreek caused a reduction in bi- omarkers of oxidative damage, coupled with increased antioxidant potential in the diabetic rats (Ravikumar and Anuradha 1999). Epidemiologic evidence also indicated that long term feeding of fenugreek seeds showed no signs of toxicity in diabetic patients (Goyal et al.,2016).Thus; it can suggest that fenugreek can be used safely for protecting against free radicals - mediated diseases, as diabetes.

Other protective action of fenugreek seeds is through reducing initiation and progression of tissue tumors (Alizadeh et al., 2009). Consumption of phenolic rich foods, as fenugreek has been proved to reduce incidence of tissue cancer (Randhir et al., 2004). However, fenugreek does not act directly as an anticarcinogenic agent, but it can suppress generation of ROS through its antioxidant activity, thereby decreasing radical mediated sequence of events leading to carcinogenesis. As support, the antioxidant constituents; flavonoids of fenugreek seeds have shown to be apoptotic in human carcinoma cells (Ahmed et al., 2000; Al-Amri and Alrasheedi, 2016). Apoptosis is a type of cell death, and agents with ability to induce apoptosis in tumor cells have the potential to be used for antitumor therapy. It appears that fenugreek flavonoids can differentially induce apoptosis in cancer cells, but not in their normal counter parts, thereby inhibit the growth of cancer cells without affecting the growth of normal cells (Alizadeh et al., 2009). This action differentiates fenugreek from chemical agents that kill both cancer and normal cells. Thus, fenugreek seems to act selectively via attacking cancer cells. Evidence supporting this was provided by (Alizadeh et al.,2009) who reported that fenu- 
greek has the ability to induce in vitro cytotoxic effect to a panel of cancer, but not normal cells. Treatment with fenugreek also showed growth inhibition to breast, pancreatic and prostate cancer cell lines (Shabbeer et al., 2009). Moreover, a potential protective effect of fenugreek seeds was observed against 7,12 - dimethylbenz (a) anthrathene (DMBA) induced breast cancer in rats (Amin et al., 2005).

In the current study, use of fenugreek seeds has demonstrated marked protection against nitrate induced-pancreatic toxicity. The protective signs included, a reduction in the levels of $\mathrm{H}_{2} \mathrm{O}_{2}$, NO and MDA in pancreatic tissue, in association with increased values of SOD, CAT, GSH, GGT and G-6-PD. This, in all, goes with consequent improvement in values of glucose, $\mathrm{HbA} 1 \mathrm{c} \%$ and insulin, as well as pancreatic tumor marker (CEA), $\alpha$-amylase and acid phosphatase activities. Thus, it can suggest that fenugreek having the ability to reduce nitrate-induced endocrine and exocrine pancreatic toxicity, primarily through inhibiting various oxidative pathways linking between diabetes and pancreatic cancer.

In conclusion, nitrate exposure can be considered as a portent agent for deterioration of both endocrine and exocrine pancreas. Accordingly, an association between high nitrate level in drinking water and incidence of diabetes and pancreatic cancer has been presently demonstrated in the two investigated ages, particularly the young one that comprise the most susceptible group to nitrate toxicity. However, feeding fenugreek seeds to all nitrate exposed rats seemed to positively affect incidence of these diseases. So, fenugreek seeds can be advised to be included in diet of population inhabiting rural areas with high nitrate levels in drinking water, in particular the more sensitive young children.

\section{Acknowledgment}

Authors are grateful to Faculty of Science, Mansoura University for providing facilities to carry out this work. 


\section{References}

Abdal Dayem, A.A., Choi, H.Y., Kim, J.H., Cho, S.G. (2010). Role of oxidative stress in stem cancer and cancer stem cells. Cancers (Basel) 2(2): 859-884.

Ahmed, N., Gupta, S., Mukhtar, H. (2000). Green tea polyphenol epigallocatechin -3 gallate differentially modulates nuclear factor kappa B in cancer cells versus normal cells. Arch Biochem Biophys, 376: 338-346.

Al-Amri, S., Alrasheedi, A. (2016). Effect of Fenugreek Seeds on Haematogenesis in Irradiated Rats. World Appl Sci J,34 (2): 147-157. Alizadeh, S., Jahanmehr, S.A., Ardjmand, A.R., Rezaian, M., Dargahi, H., Einolahi, N., Sadrossadat, M. (2009). Antineoplastic effect of fenugreek (Trigonella Foenum Graecum) seed extract against acute myeloblastic leukemia cell line (KG-1). Iran. J. Blood Cancer, 1(4): 139-146.

Amin, A., Alkaabi, A., Al-Falasi, S., Daoud, S.A. (2005). Chemopreventive activities of Trigonella Foenum Graecum (Fenugreek) against breast cancer. Cell Biol Int, 29(8):687694.

Amin, K.A., Mohamed, B.M., El-Wakil, M.A., Ibrahem, S.O. (2012). Impact of Breast Cancer and Combination Chemotherapy on Oxidative Stress, Hepatic and Cardiac Markers. J Breast Cancer, 15(3): 306-312.

Ansari, F.A. , Mahmood,R. (2015). Sodium Nitrate Induces Reactive Oxygen Species That Lower the Antioxidant Power, Damage the
Membrane, and Alter Pathways of Glucose Metabolism in Human Erythrocytes. J Agric Food Chem, 63 (48): 10372-10379.

Anwar, M.M., Mohamed N.E.( 2015). Amelioration of liver and kidney functions disorders induced by sodium nitrate in rats using wheat germ oil. J Rad Res Appl Sci, 8: 77-83.

Aschebrook-Kilfoy, B., Cross, A.J., Stolzenberg-Solomon, R.Z., Schatzkin, A., Hollenbeck, A.R., Sinha. R., Ward, M.H. (2011). Pancreatic cancer and exposure to dietary nitrate and nitrite in the NIH-AARP diet and health study. Am J Epidemiol 174(3): 305-315 Ausubel, F.M., Brent, R., Kingston, R.E., Moore, D., Seidman, J.G., Smith, J.A., Struhl, K. (1999). Current protocols in molecular biology. 1-2 Wiley Chapter 2.1.1, 10.1.4.

Basch, E., Ulbricht, C., Kuo, G., Szapary, P., Smith, M. (2003). Therapeutic applications of fenugreek. Altern Med Rev 8(1): 20-27.

Benson, V.S., Vanleeuwen, J.A., Taylor, J., Somers, G.S., McKinney, P.A., Van Til, L. (2010). Type 1 diabetes mellitus and components in drinking water and diet: a populationbased, case-control study in Prince Edward Island, Canada. J Am Coll Nutr. Dec;2:612-624.

Bock, P.P., Karmer, R., Pavelka, M. (1980). A simple assay for catalase determination. Cell Biol Monogr., 7: 44-74.

Bonelli, L., Aste, H., Bovo, P., Cavallini, G., Felder, M., Gusmaroli, R., Morandini, E., Ravelli, P., Briglia, R., Lombardo, L., De Micheli, A., Pugliese,V. (2003). Exocrine pancreatic 
cancer, cigarette smoking and diabetes mellitus: A case control study in northern Italy. Pancreas, 27(2):143-149.

Bouaziz-Ketata, H., Salah, G.B., Mahjoubi, A., Aidi, Z., Kallel, C., Kammoun, H., Fakhfakh, F., Zeghal, N.(2015). Hyparrhenia hirta: A potential protective agent against hematotoxicity and genotoxicity of sodium nitrate in adult rats. Environ Toxicol. ,Nov.30(11):1275-1284.

Boursi, B., Finkelman, B., Giantonio, B.J., Haynes, K., Rustgi, A.K., Rhim, A.D., Mamtani, R., Yang, Y.X.(2017). A Clinical Prediction Model to Assess Risk for Pancreatic Cancer Among Patients With New-Onset Diabetes. Gastroenterol, Mar;152(4):840-850.

Brindicci, C., Kharitonov, S.A., Ito, M., Elliott, M.W., Hogg, J.C., Barnes, P.J., Ito, K. (2010). Nitric oxide synthase isoenzyme expression and activity in peripheral lung tissue of patients with chronic obstructive pulmonary disease. Am J Respir Crit Care Med 181(1): 21-30.

Crohns, M., Westermarck, T., Atroshi, F. (2013). Prostate Cancer, Inflammation and Antioxidants. Advan Prostate Cancer 17:401- 421. Debrin, J.A., Sun, W., Metz, J.M., Furth, E.E. (2008). Carcinoma of the Pancreas. In: Abeloff, M.D., Armitage, J., Lichter, A.S., Niederhuber, J.E., Kastan, M.B., McKenna, W.G. (ed), Clin Oncol, 4th ed. Elsevier; Philadelphia, 1595-1609.

Doshi, M., Mirza, A., Umarji, B., Karambelkar, R.(2012). Effect of Trigonella foenumgraecum (Fenugreek/ Methi) on Hemoglobin
Levels in Females of Child Bearing Age. Biomed Res, 23 (1): 47-50.

El-Wakf, A.M. (1996). Protective effect of selenium on mercury- induced lipid peroxidation in rat kidney. J Egypt Soc Toxicol 16: 2932.

El-Wakf, A.M., Elhabiby, E.M., El-kholy, W.M., Abd El-Ghany, E.(2011). Use of tumeric and curcumin to alleviate adverse reproductive outcomes of water nitrate pollution in male rats. Nature Sci, 9: 229-239.

El-Wakf, A.M., Hassan, H.A. , Mahmoud, A.Z., Habza, M.N. (2015). Fenugreek potent activity against nitrate-induced diabetes in young and adult male rats. Cytotechnol,May,67(3):437-447.

El-Wakf, A.M., Hassan, H.A., El-Said, F.G., El-Said, A. (2009 a). Hypothyroidism in male rats of different ages exposed to nitrate polluted drinking water. Res J Medicine Med Sci 4(2): 160-164.

El-Wakf, A.M.,Hassan, H.A., El-Said, F.G., El-Said, A. (2009 b). The association between nitrate contamination of drinking water and changes in methemoglobenemia and other hematologic parameters in young and adult male rats. J Egypt Soc Toxicol., 49:91-96.

Gonen, B., Rubenstein, A.H. (1978). Heamoglobin A1 and diabetes mellitus. Diabetolog,15(1): 1-8.

Goto, T., Iijima, T., Kawano, H., Yamamoto, A., Arai, M., Matsuda, K., Yokokura, S. (2001). Serum acid phosphatase as a tumour marker in giant cell tumour of bone. Arch Orthop Trauma Surg, 121(7):411-413. 
Goyal, S., Gupta, N., Chatterjee, S. (2016). Investigating therapeutic potential of Trigonella foenum-graecum L. as our defense mechanism against several human diseases. J Toxicol., (3):1-10.

Guder, W.G., Narayana, S., Wisser, H., Zawta, B. (1996). Samples from the patient to the laboratory: The impact of preanalytical variables on the quality of laboratory results. Darmstadt Germany GIT Verlag. 1-149.

Gupta, S.K., Gupta, R.C., Chhabra, S.K., Eskiocak, S., Gupta, A.B., Gupta, R. (2008). Health issues related to $\mathrm{N}$ pollution in water and air. Indian Agri Environ Health, 94(11):14691478.

Hou, C.C., Chen, Y.P., Wu, J.H., Huang, C.C., Wang, S.Y., Yang, N.S., Shyur, L.F.(2007). A galactolipid possesses novel cancer chemopreventive effects by suppressing inflammatory mediators and mouse B16 melanoma. Cancer Res, 67(14): 6907-6915.

Huxley, R., Ansary-Moghaddam, A., Berrington de Gonzalez, A., Barz,i F., Woodward, M. (2005). Type-II diabetes and pancreatic cancer: a meta-analysis of 36 studies. $\mathrm{Br} \mathrm{J}$ Cancer,Jun.6, 92(11): 2076 - 2083.

Ilic, M. , Ilic, I.(2016). Epidemiology of pancreatic cancer. World J Gastroenterol. Nov 28;22(44):9694-9705.

Kaviarasan, S., Vijayalakshmi, K., Anuradha, C.V. (2004). Polyphenol rich extract of fenugreek seeds protects erythrocytes from oxidative damage. Plant Foods Hum Nutr, 59:143147.
Khole, S., Chatterjee, S., Variyar, P., Sharma, A., Devasagayam, T.P. A., Ghaskadbi, S. (2014). Bioactive constituents of germinated fenugreek seeds with strong antioxidant potential. J. Funct. Foods 6, 270-279.

Kusaka, G., Uno, K., Iijima, K., Shimosegawa, T. (2016). Role of nitric oxide in the pathogenesis of Barrett's-associated carcinogenesis. World J Gastrointest Pathophysiol Feb. 15; 7(1): 131-137.

Malati, T. (2007). Tumour markers: an overview. Indian J Clin. Biochem, 22 (2): 17-31.

Manimaran, A., Rajneesh, C.P. (2009). Activities of antioxidant enzyme and lipid peroxidation in ovarian cancer patients. Acad J Cancer Res, 2: 68-72.

Marienfeld, S., Hummel, S., Ziegler, A., Hummel, H. (2007). Infant nutrition and type 1 diabetes. Med, 104: A 570-575.

National Research Council, (1995). Committee on Animal Nutrition Nutrition requirements of the laboratory rats. In: Nutrient Requirements of Laboratory Animals .National Academy Press, Washington, DC, 27-38.

Nishikimi, M., Rao, N.A., Yog, K. (1972). Colormetric determination of superoxide dismutase activity. Biochem Biophys Res Commun, 46: 849-851.

Ohkawa, H., Ohish, N., Yagi, K. (1979). Assay for lipid peroxidase in animal tissues by thiobarbituric acid reaction. Anal Biochem, 95: 351-358.

Pannala, R., Basu, A., Petersen, G.M., Chari, S.T. (2009). New-onset diabetes: A potential 
clue to the early diagnosis of pancreatic cancer. Lancet Oncol, 10(1): 88-95.

Prabhu, A., Krishnamoorthy, M.(2010). Anticancer activity of Trigonella foenum graecum on Ehrlich Ascites carcinoma in Mus musculus system. J Pharm Res, 3:1181-1183.

Prins, H.K., Losse, J.A. (1969). Glutathione: biochemical methods in red cell genetics. N Y D London, 4: 126-129.

Raju, J., Gupta, D., Rao, A.R., Yadava, P.K., Baquer, N.Z. (2001), Trigonella foenum graecum (fenugreek) seed powder improves glucose homeostasis in alloxan diabetic rat tissues by reversing the altered glycolytic, gluconeogenic and lipogenic enzymes. Mol Cell Biochem, 224(1-2): 45-51.

Randhir, R., Lin, Y.T., Shetty, K. (2004). Phenolics, their antioxidant and antimicrobial activity in dark germinated fenugreek sprouts in response to peptide and phytochemical elicitors. Asia Pac J Clin. Nut, 13(3): 295-307.

Ravikumar, P., Anuradha, C.V.(1999). Effect of fenugreek seeds on blood lipid peroxidation and antioxidants in diabetic rats. Phytother Res, 13(3): 197-201.

Rückert, F., Pilarsky, C., Grützmann, R. (2010). Serum tumor markers in pancreatic cancer-recent discoveries. Cancers (Basel), 2(2): 1107-1124.

Sambrook, J., Fritsch, E.F., Maniatis, T. (1998). Molecular cloning: A laboratory manual, $2^{\text {nd }}$ Ed. Cold Spring Harbor Laboratory Press, New York.

Shabbeer, S., Sobolewski, M., Anchoori, R.K., Kachhap, S., Hidalgo, M., Jimeno, A., Davidson, N., Carduccil, M.A., Khan, S.R. (2009)
Fenugreek: A naturally occurring edible spice as an anticancer agent. Cancer Biol Ther, 8(3): 272-278.

Snedecor, C.W., Cochran, W.C.(1980). Statistical methods 7th Ed. The Stae University Press American, Iowa.

Solomon, G.M., Kirkhorn, S.R. (2009). Physicians' duty to be aware of and report environmental toxins. Virtual Mentor, 11(6):434-42.

Stayner, L.T., Almberg, K., Jones, R., Graber, J., Pedersen, M., Turyk, M. I.(2017). Atrazine and nitrate in drinking water and the risk of preterm delivery and low birth weight in four Midwestern states. Environ Res., 152:294-303.

Suja Pandian, R., Anuradha, C.V., Viswanathan, P. (2002). Gastroprotective effect of fenugreek seeds (Trigonella foenum graecum) on experimental gastric ulcer in rats. $J$ Ethnopharmacol, 81: 393-397.

Temple, R., Clark, P.M.S., Hales, C.N. (1992). Measurement of insulin secretion in type 2 diabetes: Problems and Pitfalls. Diabet Med, 9(6): 503-512.

Ward, M.H., Heineman, E.F., McComb, R.D., Weisenburger, D.D. (2005). Drinking water and dietary sources of nitrate and nitrite and risk of glioma. J Occup Environ Med ,47(12):1260-1267.

Wierusz-Wysocka, B., Wysocki, H., Byks, H., Zozulińska, D., Wykretowicz, A., Kaźmierczak, M. (1997). Metabolic control quality and free radical activity in diabetic patients. Diabetes Res Clin Pract ,27(3): 193-197. 
Xu, W., Liu, L.Z., Loizidou, M., Ahmed, M., Charles, I.G. (2002). The role of nitric oxide in cancer. Cell Res, 12(5-6): 311-320.

Yegneswaran, B., Pitchumoni, C.S.(2010). When should serum amylase and lipase levels be repeated in a patient with acute pancreatitis? Cleve Clin J Med, 77(4): 230-231.

Zavoral, M., Minarikova, P., Zavada, F., Salek, C., Minarik, M. (2011). Molecular biology of pancreatic cancer. World J Gastroenterol, 17(24): 2897-2908.

Zhai, Y., Zhao, X., Teng, Y., Li, X., Zhang, J., Wu, J., Zuo, R. (2016), Groundwater nitrate pollution and human health risk assessment by using HHRA model in an agricultural area, NE China. Ecotoxicol Environ Saf., Dec 1;137: 130-142.

Zheng, W., Wang, S.Y. (2001). Antioxidant activity and phenolic compounds in selected herbs. J Agric Food Chem 49(11): 5165-5170. 